\title{
Substance-P Prevents Cardiac Ischemia- Reperfusion Injury by Modulating Stem Cell Mobilization and Causing Early Suppression of Injury-Mediated Inflammation
}

\author{
Hyun Sook Hong ${ }^{a, b, c}$ Suna Kim ${ }^{a, b}$ Sora Lee ${ }^{d}$ Jong Shin Woo ${ }^{d}$ Kyung Hye Lee \\ Xian Wu Cheng ${ }^{d}$ Youngsook Son ${ }^{a, b}$ Weon Kim ${ }^{d}$
}

aGraduate School of Biotechnology and Department of Genetic Engineering, College of Life Science, Kyung Hee University, Yongin, Republic of Korea, 'Kyung Hee Institute for Regenerative Medicine, Kyung Hee Medical Center, Seoul, Republic of Korea, 'Department of Biomedical Science and Technology, Graduate School, Kyung Hee University, Seoul, Republic of Korea, 'Division of Cardiology, Department of Internal Medicine, Kyung Hee University Hospital, Hoegi-Dong, Republic of Korea

\section{Key Words}

Substance-P • Ischemia - Endothelial progenitor cells - Mesenchymal stem cells - Cardiac protection

\begin{abstract}
Background/Aims: Therapies using stem/progenitor cells have been experimentally and clinically investigated to regenerate damaged hearts. Substance-P (SP) induces bone marrow (BM) stem cell mobilization and suppresses inflammation in ischemic injuries. This study investigated the role of SP in BM stem cell mobilization and immune responses for tissue repair after ischemic-reperfusion injury (IRI), in comparison with that of granulocyte colonystimulating factor (GCSF). Methods: SP was intravenously injected into IRI rats and its affect was evaluated by determining colony forming efficiency, immune cell/ cytokine profiles, histological changes, and heart function through echocardiography. Results: In the rat cardiac IRI model, SP suppressed IRI-mediated tumor necrosis factor- $\alpha$ induction, but increased the levels of interleukin-10, CD206+ monocytes, and regulatory T cells in the blood; reduced myocardial apoptosis at day 1 post-IRI; and markedly stimulated colony forming unit (CFU)-e and (CFU)-f cell mobilization. Efficacy of SP in the recovery of cardiac function after IRI was demonstrated by increased cardiac contractility, accompanied by reduced infarction sizes and fibrosis, and increased revascularization of vessels covered with alpha smooth muscle actin. These effects of SP were confirmed in an acute myocardial infarction (AMI) model. All effects mediated by SP were superior to those mediated by GCSF. Conclusion: Systemic injection of




\section{Cellular Physiology Cell Physiol Biochem 2019;52:40-56 \\ \begin{tabular}{ll|l} 
and Biochem $10.33594 / 000000004$ & C 2019 The Author(s). Published by \\
Cell Physiol Biochem Press GmbH\&Co. KG
\end{tabular} \\ Hong et al.: Substance-P Inhibits Cardiac Ischemia-Reperfusion Injury}

SP decreased early inflammatory responses and promoted stem cell mobilization, leading to a compact vasculature and improved cardiac function in cardiac IRI and AMI.

\section{Introduction}

Acute myocardial infarction (AMI) is the irreversible loss of cardiac function as a consequence of prolonged ischemia with excessive inflammation and is a leading cause of morbidity and mortality. Recently, diverse cellular therapies using stem/progenitor cells have been experimentally and clinically investigated to regenerate the damaged heart [1-3]. Studies on the trafficking of endothelial progenitor cells (EPCs) in tissue repair under AMI and hind limb ischemia found that growth factors, such as granulocyte colonystimulating factor (GCSF), vascular endothelial growth factor (VEGF), and stromal derived factor-1 (SDF-1), are the potential regulators required for trafficking of haematopoietic stem cells (HSCs) and EPCs from the bone marrow (BM) reservoir [4-11]. Importantly, neo-vascularization requires pericytes as well as endothelial cells. Pericytes are important regulators of angiogenesis and vascular stability [12-14], secreting pro-angiogenic factors at the onset of angiogenesis. EPCs and mesenchymal stem cells (MSCs) are reported to be the reparative stem/progenitor cells for endothelial cells and pericytes, respectively [15-16]. Therefore, it could be inferred that coexistence of EPCs and MSCs contribute to the formation of pericyte-covered vasculature under ischemic conditions. Unfortunately, factors that facilitate EPC and MSC mobilization have not been identified, and there are few transplantation studies on both EPC and MSCs. GCSF, the representative factor to mobilize EPCs from the BM into the circulation, is used clinically in ischemic diseases but was found to minimally affect MSC mobilization $[6,17]$.

Substance-P (SP), a highly conserved, 11-amino acid neuropeptide, which is expressed in non- myelinated sensory neurons and in various non-neural cells [18], induces mobilization of bone marrow BMSCs [19], and suppresses inflammation in diverse diseases, including spinal cord injury, diabetic ulcers, and rheumatoid arthritis [20-24]. Considering the coordinated interplay that occurs among multiple wound-healing phases, the early resolution of injury-induced inflammation and the removal of dead cells might be essential steps to provide a more receptive microenvironment for the survival and engraftment of the incoming reparative stem cells during tissue repair. Thus, if SP has the ability to suppress injury-induced inflammation in the early phases of tissue injury, as well as its stem cellmobilizing capacity, it might facilitate tissue repair more effectively than other stem cell mobilizers that retain their pro-inflammatory function, such as GCSF and VEGF [25-28].

In this study, we examined whether SP could mobilize both EPCs and BMSCs from the $\mathrm{BM}$ to the peripheral blood (PB) by intravenous injection of SP under normal physiological conditions. To evaluate the therapeutic function of SP in disease conditions, we injected SP into a rat model of cardiac ischemic-reperfusion injury (IRI) and assessed how much endogenous SP is induced under IRI and whether it is sufficient to mobilize reparative stem cells to achieve tissue repair. Moreover, SP-mediated suppression of early inflammation was determined by checking cytokine profiles and the immune cell pool in the circulation. Additionally, the role of SP was also explored in an AMI model.

\section{Materials and Methods}

\section{Reagents}

MSCGM and EGM media (Lonza, Basel, Switzerland), phosphate-buffered saline (PBS, Welgene, Daegu, Korea), and SP (Sigma-Aldrich, St. Louis, MO, USA) were obtained from the indicated suppliers. Enzymelinked immunosorbent assay (ELISA) kits for SP, TNF-alpha (TNF- $\alpha$ ), and interleukin-10 (IL-10) were from R\&D systems (Minneapolis, MN, USA). 


\section{Cellular Physiology Cell Physiol Biochem 2019;52:40-56 \begin{tabular}{ll|l} 
and Biochemistry & $\begin{array}{l}\text { DOl: 10.33594/000000004 } \\
\text { Published online: } 18 \text { February 2019 }\end{array}$ & $\begin{array}{l}\text { 2 2019 The Author(s). Published by } \\
\text { Cell Physiol Biochem Press GmbH\&Co. KG }\end{array}$ \\
\cline { 2 - 3 }
\end{tabular} \\ Hong et al.: Substance-P Inhibits Cardiac Ischemia-Reperfusion Injury}

Rat IRI and AMI model

Male Sprague-

Dawley rats, 8-9-week-old, weighing 250-280 g, were obtained from Orient. Bio Inc. (Seongnam, Korea) and were used after a oneweek acclimatization period under standard laboratory conditions. To prepare the IRI model, the left anterior descending (LAD) coronary artery of the rat was ligated for $40 \mathrm{~min}$. Immediately after reperfusion, SP $(6.7 \mu \mathrm{g} /[\mathrm{kg} \bullet 0.1 \mathrm{ml}])$ or G-CSF $(10 \mu \mathrm{g} /[\mathrm{kg} \bullet 0.1 \mathrm{ml}])$ was intravenously(i.v.) injected. The treated dose of SP was determined after the effect of diverse concentrations of SP on stem cell mobilization and immune suppression was evaluated (Table 1). The rats were sacrificed at $10 \mathrm{~min}, 1 \mathrm{~h}$, and $4.5 \mathrm{~h}$ post injection of SP for fluorescence-activated cell sorting (FACS) and ELISA analysis; at day 1 for apoptosis experiments; at days 3, 5, 7 for CFU-e and CFU-f analysis and complete blood cell counting (CBC) analysis.

For AMI induction, the LAD artery was permanently ligated. SP or G-CSF was i.v. injected twice a week for 2 weeks. Saline was used as vehicle. Control animals consisted of infarcted and shamoperated rats injected with saline at 1 and 8 weeks for histological analysis, TTC staining, and MTC staining.

All animal studies were approved by the Ethical Committees for Experimental Animals at Kyung Hee University (KHMC-IACUC-14-010). The methods of animal experiments were carried out in accordance with guideline and regulation approved by the Institutional Animal Care and Use Committee.

\section{MTC staining}

To observe collagen deposition in the wound region, MTC Staining (IHC World, Woodstock, MD, USA) was performed according to the manufacturer's instructions. Briefly, paraffin-sectioned samples $(4 \mu \mathrm{m}$ thick) were deparaffinized, hydrated, and fixed in Bouin's solution (Sigma-Aldrich) for $1 \mathrm{~h}$ at $56{ }^{\circ} \mathrm{C}$. After washing in distilled water, the samples were stained with Weigert's hematoxylin for 10 min, Biebrich scarlet-acid fuchsin for $2 \mathrm{~min}$, phosphomolybdic-phosphotungstic acid solution for $10 \mathrm{~min}$, and aniline blue for $10 \mathrm{~min}$. After washing with distilled water, the samples were treated with $1 \%$ acetic acid (SigmaAldrich) for $5 \mathrm{~min}$, and then dehydrated, mounted, and observed using a Nuance Multiplex Biomarker Imaging System (Cambridge Research Instrumentation, Woburn, MA, USA).

\section{Immunohistochemical staining}

Immunohistochemical staining was performed using the VECTASTAIN ABC Kit (Vector Laboratories, Burlingame, CA, USA), following the manufacturer's protocol. Samples were treated with 0.5\% H2O2 to block endogenous hydrogen peroxidase activity for $10 \mathrm{~min}$ and permeabilized with $0.3 \%$ Triton- X100. Nonspecific binding sites were blocked by incubating the samples with 1\% normal horse serum for $1 \mathrm{~h}$ at room temperature (RT). Primary antibodies against mouse CD31 (ab64543, Abcam, Cambridge, MA, USA), SP (ab14184, Abcam), $\alpha$-SMA (ab5694, Abcam), or cleaved caspase 3 (9661, Cell Signaling Technology, Danvers, MA, USA) were added. After washing in PBS three times, the samples were incubated with a biotin-conjugated secondary antibody for $1 \mathrm{~h}$ at RT. After washing in PBS, substrate solution was added and maintained at RT for $40 \mathrm{~min}$. To visualize the reactive areas in the tissues, samples were treated with dimethyl-aminoazobenzene (DAB; Vector Laboratories), counterstained with Fast Red (Vector Laboratories) for $10 \mathrm{~min}$, and mounted. Finally, samples were observed under a Nuance Multiplex Biomarker Imaging System. All quantitative analyses were performed using six adjacent fields (1.5 mm2) on temporal slides. 


\section{Cellular Physiology Cell Physiol Biochem 2019;52:40-56 \\ \begin{tabular}{ll|l} 
and Biochemistry & $\begin{array}{l}\text { DOl: 10.33594/000000004 } \\
\text { Published online: } 18 \text { February 2019 }\end{array}$ & $\begin{array}{l}\text { 2019 The Author(s). Published by } \\
\text { Cell Physiol Biochem Press GmbH\&Co. KG }\end{array}$ \\
\cline { 2 - 3 }
\end{tabular} \\ Hong et al.: Substance-P Inhibits Cardiac Ischemia-Reperfusion Injury}

ELISA

Cytokine profiles in tissue, serum, and bone marrow aspirates were analyzed by ELISA (R\&D Systems, Minneapolis, MN), with all reagents, standard dilutions, and samples prepared as directed in the manufacturer's instructions. Subsequently, $100 \mu \mathrm{L}$ and $50 \mu \mathrm{L}$ of calibrator diluent were added to the nonspecific binding and zero standard (B0) wells, respectively. In the remaining wells $50 \mu \mathrm{L}$ of the standard, control, or sample were added. Next, $50 \mu \mathrm{L}$ of primary antibody solution was added to each well, followed by $100 \mu \mathrm{L}$ of horseradish peroxidase-conjugated secondary antibody; the plates were incubated for $2 \mathrm{~h}$. The samples were then incubated with $100 \mu \mathrm{L}$ of substrate solution. Once the color of the solution changed to blue, the reaction was stopped, and the optical density was measured at a wavelength of $450 \mathrm{~nm}$ using an EMax Endpoint ELISA Microplate Reader (Molecular Devices, Sunnyvale, CA, USA).

\section{FACS analysis}

Peripheral blood mononuclear cells (PBMCs) were isolated from $8 \mathrm{ml}$ of peripheral blood (PB) using a ficoll gradient (GE healthcare, Buckinghamshire, UK). For analysis of regulatory $\mathrm{T}$ cells $\left(\mathrm{T}_{\mathrm{reg}} \mathrm{s}\right.$ ) in PBMCs, the FoxP3 Intracellular Staining Kit (BioLegend, San Diego, CA, USA) was used; $2 \times 10^{7}$ PBMCs were fixed and then incubated with PE-conjugated anti-FoxP3 antibody and APC-conjugated CD4 antibody (BioLegend, San Diego, CA, USA) for $30 \mathrm{~min}$ at $4{ }^{\circ} \mathrm{C}$ in the dark. To analyze the M2-skewed monocyte phenotype in PBMCs, $1 \times 10^{7}$ PBMCs were incubated with an APC-conjugated anti-CD11b antibody (BioLegend) and then with a FITC-conjugated anti-CD206 antibody (Abcam) for 30 min at $4{ }^{\circ} \mathrm{C}$, in the dark. After washing twice with FACS buffer, the proportion of $\mathrm{T}_{\text {reg }} \mathrm{s}$ and M2-phenotype monocytes in PBMCs was analyzed using a FACSCalibur flow cytometer and the CELLQuest software (Becton Dickinson, San Jose, CA, USA).

\section{Measurement of left ventricular (LV) function}

Transthoracic echocardiography (Sonos 5500, Philips, Bothell, WA, USA) was performed to evaluate LV function, as described previously [29]. Under anesthesia, the chest was shaved, and 2-dimensional, M-mode images were taken at 1 week after IRI and 2, 4 and 8 weeks after AMI, using a 15-MHz linear probe. M-mode images of the LV were obtained from the parasternal short-axis view at the level of the papillary muscles and from the parasternal long axis view. Parameters were averaged from three cardiac cycles. The $\mathrm{LV}$ ejection fraction $(\% \mathrm{EF})$ and fractional shortening $(\% \mathrm{FS})$ were automatically calculated by the echocardiographic system.

\section{Statistical analysis}

All data are presented as the mean \pm standard deviation (SD). Student's t-test (for comparisons between two groups) and one-way analysis of variance (ANOVA; for comparisons of three or more groups, followed by Tukey's post-hoc test) were performed. Probability values less than 0.05 were interpreted to indicate statistically significant differences $\left({ }^{*} \mathrm{p}<0.05,{ }^{* *} \mathrm{p}<0.01,{ }^{* * *} \mathrm{p}<0.001\right)$.

\section{Results}

IRI-induced endogenous SP expression minimally stimulated EPC and BMSC mobilization, which could be substantially boosted by SP injection after IRI

Recently, SP was found to stimulate mobilization of reparative stem cells into the blood circulation, leading to tissue repair. The cell mobilizing capacity of SP prompted us to explore its role in cardiac protection and recovery from AMI. First, we examined the capacity of SP to mobilize neurokinin receptor $1(\mathrm{NK} 1 \mathrm{R}+)$ EPCs and BMSCs in non-injured normal rats by fluorescence activated cell sorting (FACS) analysis on day 3 post-SP injection (Fig. 1A and B). SP injection elevated NK-1R+ cells in the PB, and this population included CD29+, CD90+, and CD31+ cells. NK-1R+ cells from the PB were cultured in endothelial cell growth medium (EGM) or mesenchymal stem cell growth medium (MSCGM), respectively, and colony forming efficiency was evaluated (Fig. 1C-E). SP increased the colony- forming stem cell population in the circulation, compared with that observed in the saline-treated group. 


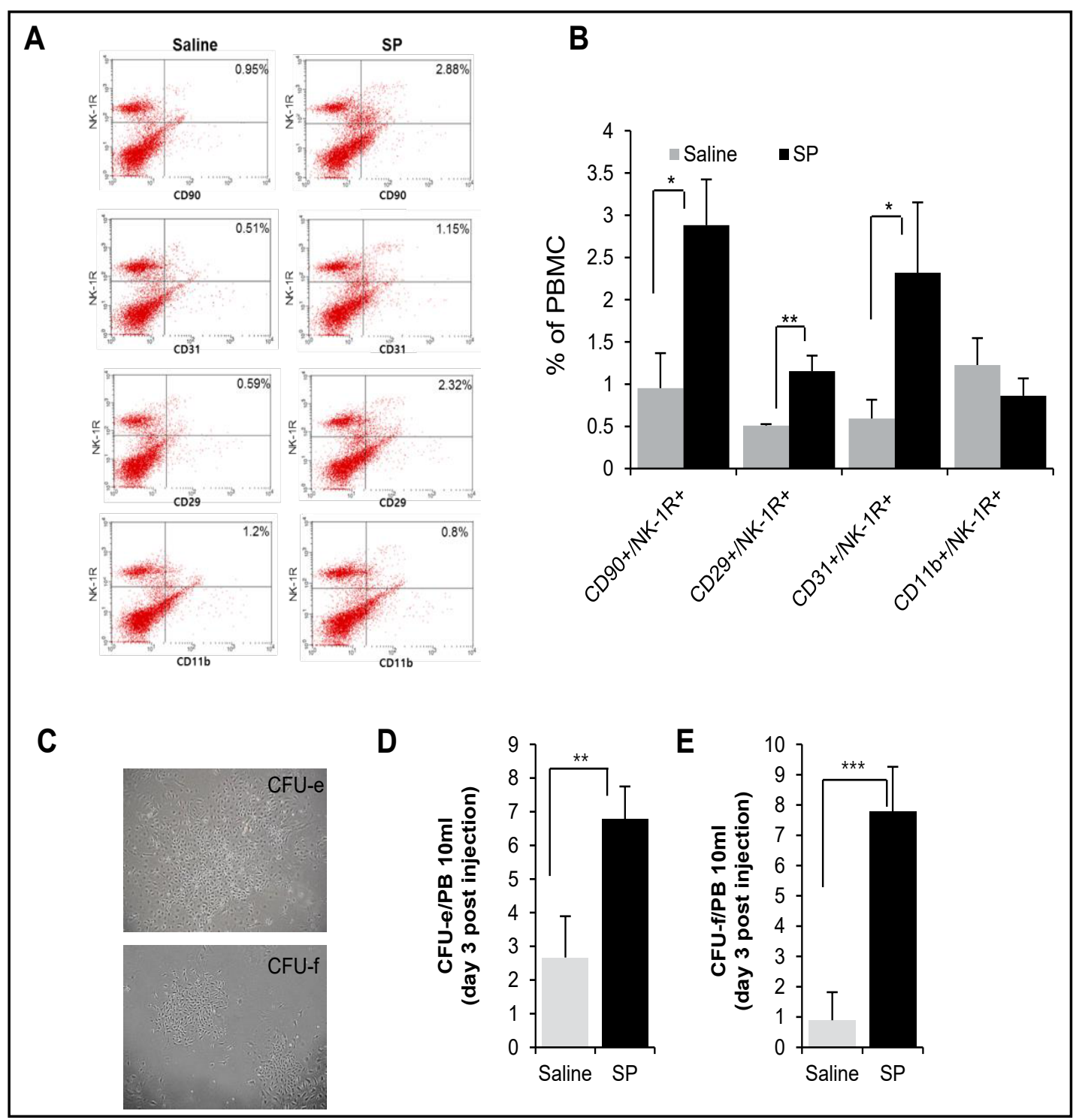

Fig. 1. Mobilization of endothelial progenitor cells (EPCs) and bone marrow mesenchymal stem cells (BMSCs) by substance P (SP) under normal conditions. SP-induced EPCs and BMSCs mobilization in normal rats. SP was intravenously injected into rats, and peripheral blood mononuclear cells (PBMCs) from 10 $\mathrm{ml}$ blood on day 3 were harvested for fluorescence activated cell sorting (FACS) analysis (A-B) and colony forming unit (CFU)-e and CFU-f assay (C-E). Results are shown as the mean \pm SD. Statistical significance was considered when ${ }^{*} \mathrm{p}<0.05,{ }^{* *} \mathrm{p}<0.01$, and ${ }^{* * *} \mathrm{p}<0.001$ compared to saline group.

After confirmation of stem cell mobilization by SP in non-injured normal rats, we evaluated SP in a cardiac injury model. The IRI model and experimental design are represented in Fig. 2A. We determined how much endogenous SP was induced by IRI in the injured cardiac tissue, blood, and BM (Fig. 2B and C). IRI itself clearly induced endogenous SP expression in infarcted areas and in the serum, but no SP reactivity was detected in the sham-operated group or in the contralateral side of the IRI groups (Fig. 2B). One hour after IRI, the SP level in the blood increased approximately 4-fold (Fig. 2C) compared with that in the sham group, but no significant change in SP levels in the bone marrow (BM) was observed. This IRI-induced SP increase in the blood was maintained for up to 1 day and then declined from day 3 post-IRI (Fig. 2D). Thus, IRI itself can induce an increase in endogenous SP production at the injury site of cardiac tissue as early as $10 \mathrm{~min}$ and in the PB at $1 \mathrm{~h}$, which 


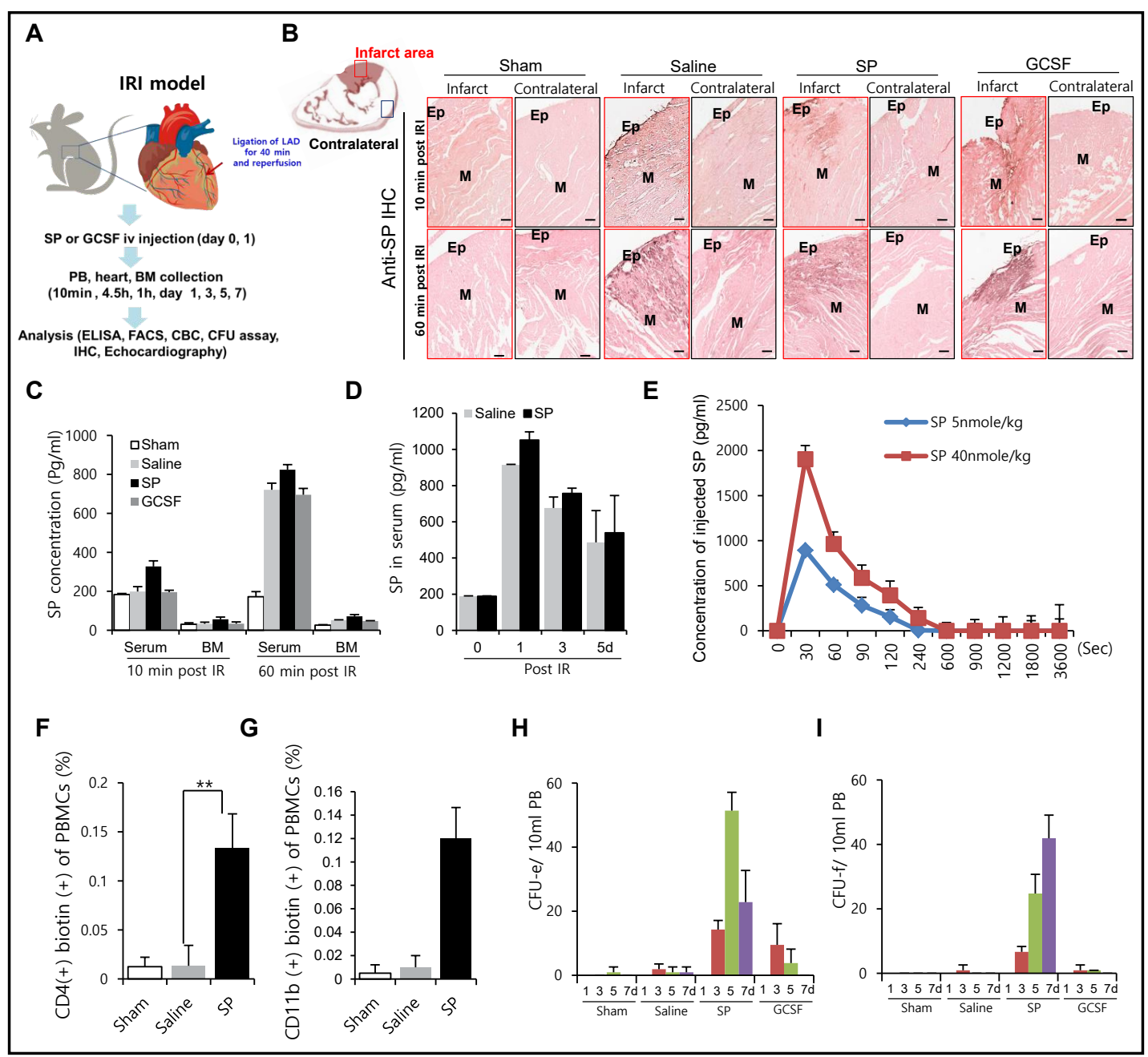

Fig. 2. Detection of endogenous substance $P(S P)$ elevation and mobilization of endothelial progenitor cells (EPCs) and bone marrow mesenchymal stem cells (BMSCs) during ischemia reperfusion injury (IRI). (A) Schematic model of IRI in SD rats and experimental the schedule. SP or granulocyte colony- stimulating factor (GCSF) was intravenously injected immediately after reperfusion. (B) Immunohistochemistry of SP in the paraffin-sectioned cardiac tissue of the infarcted zone and the contralateral side. EP: epicardium, M: myocardium. Scale bar: $100 \mu \mathrm{m}$. (C, D) Enzyme-linked immunosorbent assay (ELISA) of SP in the blood and bone marrow (BM) at $10 \mathrm{~min}$ and 60 min post- saline, SP, or GCSF injection after IRI, and in the blood on days 1-5 post-IRI. (E) Analysis for pharmacokinetic parameters of SP in the blood. (F, G) At 10 min after Biotin-SP injection in the IRI model, PBMCs were isolated. Biotin-SP bound cells were detected by FITC-streptavidin, $\mathrm{CD} 4{ }^{+} \mathrm{T}$ cells were determined by APC-conjugated CD4 antibody, CD11b monocytes were determined by APC- conjugated anti-CD11b antibody, and followed by FACS analysis. (H, I) Comparison of CFU-f and CFU- e cell-mobilization kinetics in the sham-operated $(n=6)$, IRI + saline $(n=$ $6), I R I+S P(n=6)$, and IRI + GCSF $(n=6)$-injected groups. The data are shown as the mean \pm SD. ${ }^{*} p<0.05$, ${ }^{* *} \mathrm{p}<0.01,{ }^{* * *} \mathrm{p}<0.001$.

can last up to 1-day post-IRI. However, even a bolus injection of SP (6.7 $\mu \mathrm{g} /[\mathrm{kg}, 0.1 \mathrm{~mL}])$ or GCSF $(10 \mu \mathrm{g} /[\mathrm{kg}, 0.1 \mathrm{~mL}])$ immediately after IRI did not affect the SP level at the steady state in the serum or BM of the animals (Fig. 2C). This might reflect the pharmacokinetics of SP, considering that a bolus SP injection decayed very rapidly, with $\mathrm{a}^{\mathrm{t}}{ }_{1 / 2}$ of $0.69 \pm 0.43$ min (Fig. 2E). Although it is rapidly cleared from the blood, i.v.-injected biotin-SP could be detected on CD4+ and CD11b+ peripheral blood mononuclear cells (PBMCs) 10 min after the injection (Fig. 2F and G) and on CD29+ cell clusters $2 \mathrm{~h}$ after BM harvest [19] 
to examine whether the immediate IRI-induced SP rise in the PB can stimulate stem cell mobilization substantially, the mobilization of both EPCs and BMSCs after IRI, IRI + SP injection, or IRI + GCSF injection was measured sequentially up to day 7 post-IRI (Fig. $2 \mathrm{H}$ and I). Although IRI-induced SP elevation in the serum was clearly noticed, IRI itself only marginally increased the number of CFU-e and CFU-f cells in the PB, which could be markedly boosted by SP injection, starting on day 3 and peaking on day 5 for the CFU-e cells and day 7 for the CFU-f cells. Thus, the IRI-induced SP increase did not seem to initiate substantial mobilization of EPCs and BMSCs for tissue repair; however, with SP injection just after the IRI, this requirement for tissue repair could be met. In contrast, GCSF injection after IRI only slightly enhanced CFU-e cell mobilization but did not mobilize CFU-f cells at all. Accordingly, SP injection after IRI clearly accelerated reparative stem cell mobilization at a much higher rate than that observed with IRI-induced endogenous response and GCSF injection.

\section{SP reduced myocardial cell death, accompanied by inhibiting inflammatory responses}

Regarding IRI-induced systemic inflammatory responses, IRI itself increased the neutrophil ratio in total leukocytes up to day 5 (Fig. 3A) and increased TNF- $\alpha$ in the serum on day 1 post-IRI (Fig. 3B), corresponding to an injury-mediated inflammatory response, which regressed from day 3 post-IRI. This systemic IRI-mediated increase in TNF- $\alpha$

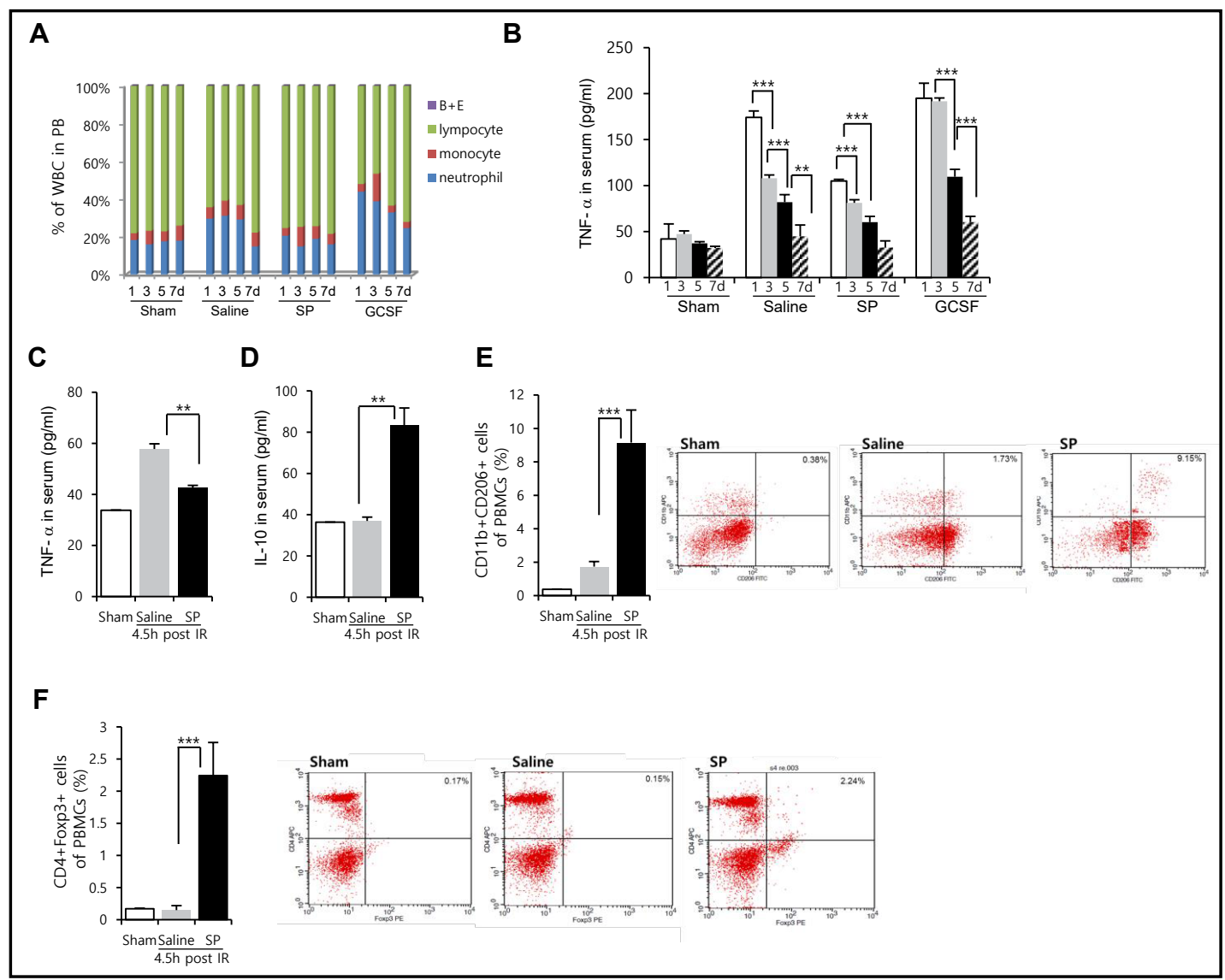

Fig. 3. Regulation of ischemia reperfusion injury (IRI)-induced inflammation by substance $P$ (SP) injection. (A) IRI-induced systemic inflammatory responses were evaluated by complete blood cell counting (CBC) analysis and (B-F) Enzyme-linked immunosorbent assays (ELISA) against TNF- $\alpha$ (B, C) and IL-10 (D) in the serum, and (E) fluorescence activated cell sorting (FACS) analysis of CD11b ${ }^{+}$CD206 $^{+}$ M2-phenotype monocytes and (F) CD $4^{+}$Foxp $3^{+}$Treg cells in peripheral blood mononuclear cells (PBMCs). The data are shown as the mean \pm SD. ${ }^{*} \mathrm{p}<0.05,{ }^{* *} \mathrm{p}<0.01,{ }^{* * *} \mathrm{p}<0.001$. 


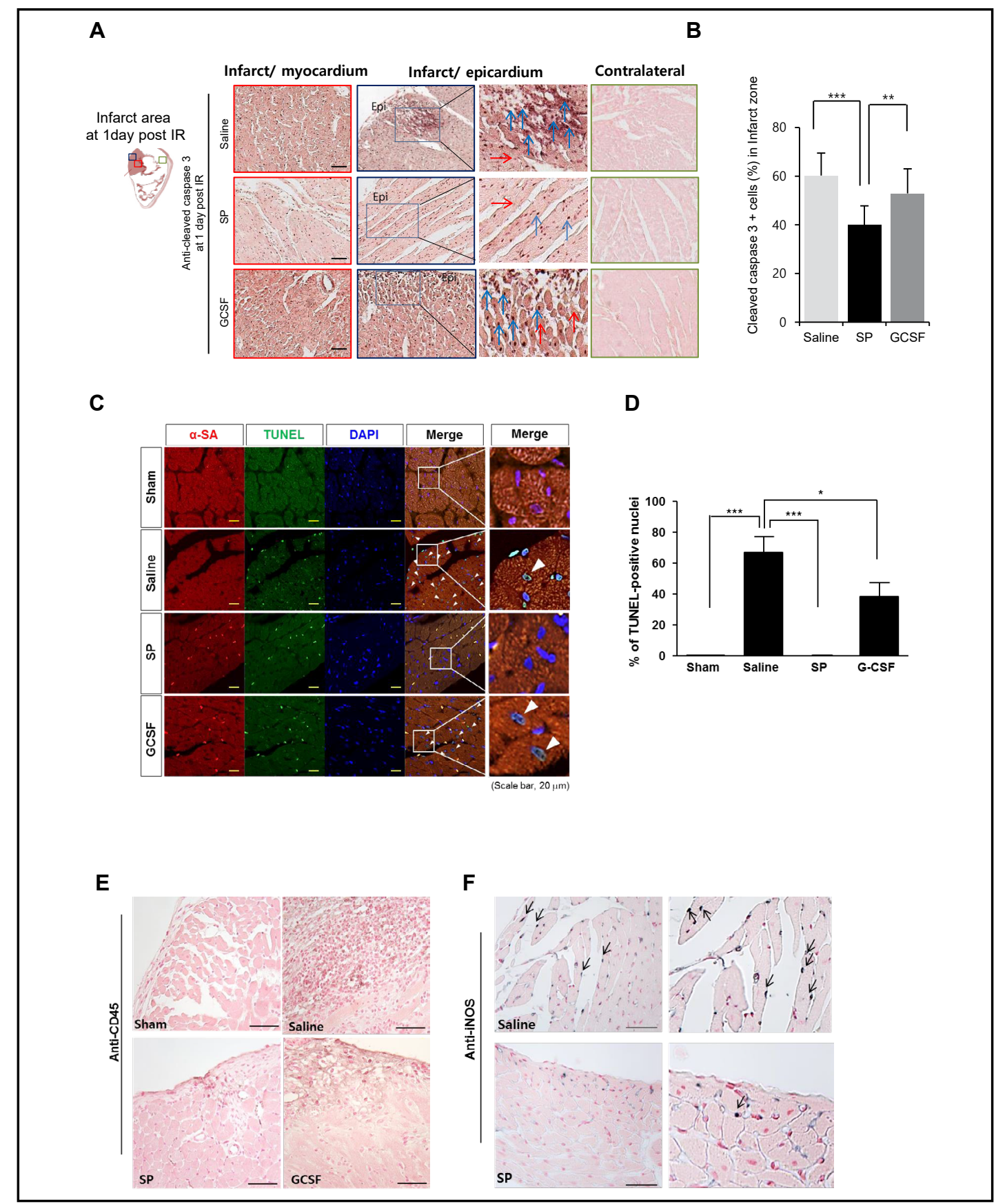

Fig. 4. Regulation of ischemia reperfusion injury (IRI)-induced myocardial apoptosis by substance P (SP) injection. Comparison of apoptosis within the infarct zone 1day post-IRI with SP injection versus GCSF injection by immunohistochemical staining. (A, B) The blue arrow indicates cleaved caspase $3(+)$ apoptotic cells and the red arrow indicates normal cells. Sham-operated $(n=4)$, IRI + saline $(n=6)$, IRI + SP $(n=6)$, IRI + GCSF $(n=6)$. Scale bar: $100 \mu m$. (C, D) SP was intravenously injected to rats 1 day post IR and apoptotic cardiac myocytes were determined with TUNEL (FITC), sarcomeric $\alpha$-actinin (TRITC) and DAPI staining. TUNEL-positive myocyte nuclei were observed by confocal microscopy LSM700 (Carl Zeiss, Germany) and analyzed from five different high-power fields (X 400). White arrows indicate TUNEL- and sarcomeric $\alpha$-actinin-positive nuclei. (E, F) Immunohistochemical staining for CD45 and iNOS in cardiac tissue post IR. SP was intravenously injected into rats post IR and inflammatory cells in cardiac tissue was determined by staining for CD45 (leukocyte) and iNOS (activated macrophage). Scale bar: $50 \mu \mathrm{m}$. Black arrow: iNOS+ cell The data are shown as the mean \pm SD. ${ }^{*} \mathrm{p}<0.05,{ }^{* *} \mathrm{p}<0.01,{ }^{* * *} \mathrm{p}<0.001$. 
production was abrogated by SP injection but was further extended up to day 3 by GCSF injection. Clearly, GCSF increased the inflammation burden after IRI.

To determine the effects of SP on blood cells and systemic inflammatory responses during the early stages of IRI and cell death of cardiac tissue (which probably occurs before the effects of SP on stem cell mobilization), cytokines such as TNF- $\alpha$ and IL-10, circulatory $\mathrm{M} 2$ monocytes, and $\mathrm{T}_{\text {reg }} \mathrm{S}$ in the $\mathrm{PB}$ were analyzed at $4.5 \mathrm{~h}$ post-IRI (Fig. 3C-F). At $4.5 \mathrm{~h}$ post-injection, SP blunted the IRI-mediated TNF- $\alpha$ induction (Fig. 3C) but increased the levels of the anti-inflammatory cytokine IL-10 in the blood (Fig. 3D). Furthermore, SP markedly increased the numbers of CD11b+/CD206+ cells (Fig. 3E) and CD4+/Foxp3+ cells (Fig. 3F) in the blood. Cleaved-caspase 3 in the injured cardiac tissue was measured on day 1 post-IRI using immunohistochemical staining (Fig. 4). At day 1 after IRI, fewer apoptotic myocytes (positive for cleaved caspase-3 and TUNEL-positive; Fig. 4A-D) and fewer infiltrated leukocytes were detected in the SP-injected group compared with those in the saline- or GCSF- injected groups. Notably, more iNOS+ M1 macrophages of infiltrated leukocytes were present in saline-injected group than in SP-injected group (Fig. $4 \mathrm{E}$ and F).

Accordingly, the early mitigation of IRI-induced inflammatory responses mediated by SP might substantially reduce the apoptosis of cardiac tissue in the early phase.

SP improved the recovery of cardiac function after IRI by reducing the infarction size and fibrosis, and by increasing revascularization with $\alpha$-SMA-covered vessels; these effects were superior to those of GSCF

To investigate whether early treatment with SP or GCSF after IRI could affect the recovery of cardiac function, echocardiograms were performed at 1-week post-IRI (Fig. $5 \mathrm{~A}-\mathrm{E}$ and Table 2). The injection of SP after IRI resulted in higher left ventricular fractional shortening (FS) and left ventricular ejection fraction (EF) than that observed in the saline or GCSF-injected groups (EF: $59.3 \pm 4.79 \%$ [saline], 76.56 $\pm 1.18 \%$ [SP], 71.11 $\pm 1.52 \%$ [GCSF]; FS: $28 \pm 3.09 \%$ [saline], $40.7 \pm 1.27 \%$ [SP], 37.24 $\pm 1.09 \%$ [GCSF]).

The SP-mediated improvement in cardiac function was further analyzed by triphenyltetrazolium chloride (TTC) staining (Fig. 6A and B) and Masson trichrome (MTC) staining (Fig. 6C and D) at 1-week post-IRI. SP treatment markedly reduced IRI-mediated infarction size $(73.4 \pm 11.6 \%$ [saline], $31 \pm 14.2 \%$ [SP], 57.7 $\pm 8.3 \%$ [GCSF] $)$ and IRI-mediated cardiac fibrosis $(14.9 \pm 4.2 \%$ [saline], $2.7 \pm 1.0 \%$ [SP], $7.2 \% \pm 2.4 \%$ [GCSF]).

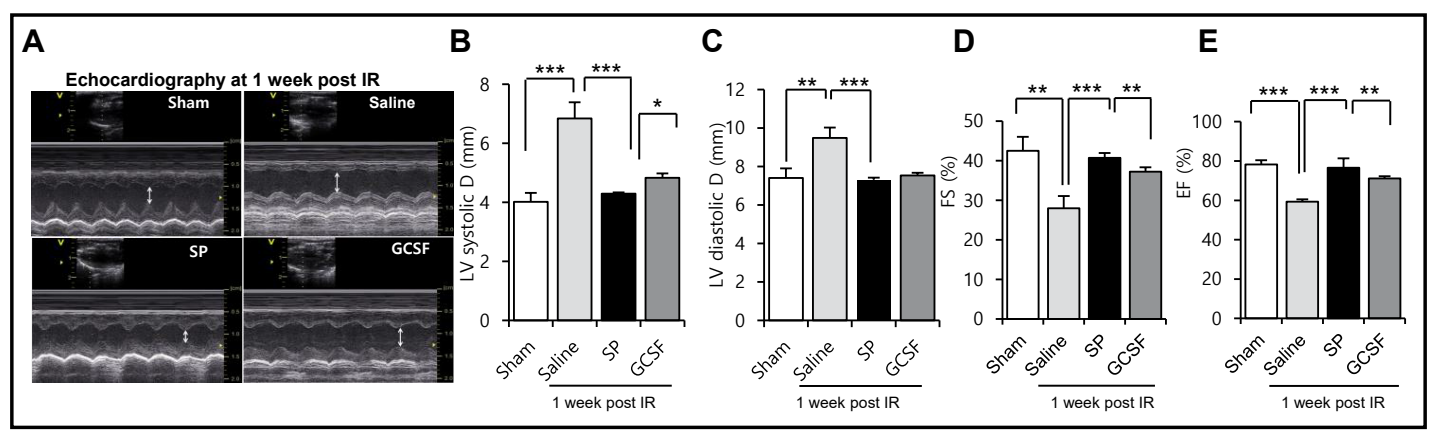

Fig. 5. Substance P (SP)-mediated improvements after ischemia reperfusion injury (IRI) versus those observed after granulocyte colony-stimulating factor (GCSF) injection, based on echocardiographic analysis. SP or GCSF was injected twice on days 0 and 1 post-IRI and echocardiograms were taken 1 week post- IRI. (A) Representative echocardiogram images for each group. (B) Left ventricle (LV) systolic dimension, (C) $\mathrm{LV}$ diastolic dimension, (D) \%FS (fractional shortening), and (E) \%EF (ejection fraction). Sham-operated $(n=10), I R I+$ saline $(n=12), I R I+S P(n=12), I R I+G C S F(n=12)$. The data are shown as the mean \pm SD. ${ }^{*} \mathrm{p}<0.05,{ }^{* *} \mathrm{p}<0.01,{ }^{* * *} \mathrm{p}<0.001$. 


\section{Cellular Physiology Cell Physiol Biochem 2019;52:40-56 \\ \begin{tabular}{ll|l} 
and Biochemistry & $\begin{array}{l}\text { DOl: 10.33594/000000004 } \\
\text { Published online: } 18 \text { February } 2019\end{array}$ & $\begin{array}{l}\text { O 2019 The Author(s). Published by } \\
\text { Cell Physiol Biochem Press GmbH\&Co. KG }\end{array}$ \\
\cline { 2 - 3 }
\end{tabular} \\ Hong et al.: Substance-P Inhibits Cardiac Ischemia-Reperfusion Injury}

To estimate the vascular integrity in the repaired tissue, vascular density and structural integrity were measured in the peri-infarct zone, infarct zone, and non-infarct contralateral zone using immunohistochemical staining against CD31 for endothelial cells and $\alpha$-SMA for pericytes (Fig. 6E-G). The CD31+ vessel density was highest in the saline-injected IRI group, but approximately $20 \%$ of the vessels were covered by $\alpha$-SMA+ pericytes at the peri-infarct zone and infarct zone. However, in the SP-injected IRI group, the vessel density was lower than that in the saline-injected IRI group, but more than $50 \%$ of the vessels at the peri-infarct zone and infarct zone were covered by $\alpha$-SMA+ cells. In the GCSF-injected IRI group, approximately $20 \%$ of the vessels at the infarct zone were covered by $\alpha$-SMA+ pericytes, which was similar to that observed in the saline-injected group, but approximately $40 \%$ of the vessels at the peri-infarct zone were covered by $\alpha$-SMA+ pericytes. The pericytescovered vascular structure was confirmed by PDGFR + vessel counting in infarct zone and peri-infarct zone (Fig. $6 \mathrm{H}$ and I).

Taken together, our findings indicate that SP might work more effectively in vascular regeneration by mobilizing both EPCs and BMSCs, and by inducing their recruitment towards the healing tissue.

Repetitive SP treatments after permanent ligation of the left anterior descending (LAD) artery improved cardiac function

We further explored the efficacy of SP treatment on the recovery of cardiac function after permanent ligation in the LAD artery model, which requires more extensive tissue repair and neovascularization than the IRI model (Fig. 7). After permanent LAD ligation, SP or GCSF was injected twice a week for 2 weeks, and echocardiograms were performed at 4 and 8 weeks (Fig. 7A-G and Table 3). SP treatment also markedly improved the recovery of cardiac function in the permanent ligation model at 4 weeks (EF: $73.6 \pm 0.6 \%$ [sham], $56.7 \pm 2.9 \%$ [saline], $66.2 \pm 1.3 \% \%$ [SP], $61.2 \pm 1.4 \%$ [GCSF] $)$ and at 8 weeks $(74.7 \pm 0.4 \%$ [sham], 52.8 $\pm 1.4 \%$ [saline], $72 \pm 1.9 \%$ [SP], 62.8 $\pm 2.5 \%$ [GCSF]). A clear difference was also observed in the $\% \mathrm{FS}$ between the groups at 4 weeks (37.9 $\pm 0.4 \%$ [sham], $25 \pm 1.3 \%$ [saline], $33.2 \pm 0.9 \%$ [SP], $30.9 \pm 1.3 \%$ [GCSF] $)$ and at 8 weeks $(39.1 \pm 0.5 \%$ [sham], $24.0 \pm 0.8 \%$ [saline], $36.8 \pm 1.5 \%$ [SP], 30.1 $\pm 1.7 \%$ [GCSF]).

Histological analysis further confirmed the recovery of cardiac function by SP (Fig. 8A-F). SP decreased the infarction area, as revealed by TTC staining $(71.7 \pm 15.5 \%$ [saline] $33.9 \pm 8.6 \%$ [SP], $\quad 52 \pm 10.8 \%$ [GCSF]; Fig. 8A) and also decreased the fibrosis area, as observed by MTC staining $\quad(24.1 \pm 3.1 \%$ [saline], $\quad 9.8 \pm 1.8 \%$ [SP], $\quad 16.4 \pm 2.5 \%$ [GCSF]; Fig. 8B and C). Both GCSF and SP resulted in higher vessel numbers in the infarct core than those in the shamoperated and saline groups; however, the group receiving SP treatment showed more vessels covered by $\alpha$-SMA-expressing cells than in the

Table 2. Echocardiographic analysis at 1 week post IR. HR, heart rate; IVS, interventricular septal thickness in diastole; PW, posterior wall thickness in diastole; LV diastolic D, left ventricle diastolic dimension; LV systolic D, left ventricle systolic dimension; LVEDV, LV end diastolic volume; LVESV, LV end systolic volume; EF, ejection fraction; FS, fractional shortening. Values represent mean \pm SEM. ${ }^{*} \mathrm{p}<0.05,{ }^{* *} \mathrm{p}<0.01,{ }^{* *} \mathrm{p}<0.001$ (compared with Saline)

\begin{tabular}{lcccc}
\hline Parameter & Sham & Saline & SP & GCSF \\
\hline 1week post IR & & & & \\
HR & $284 \pm 5.7$ & $265 \pm 15.4$ & $245.5 \pm 20.5$ & $242.3 \pm 23.3$ \\
IVS & $1.78 \pm 0.08$ & $1.49 \pm 0.24$ & $1.65 \pm 0.14$ & $1.65 \pm 0.16$ \\
PW & $1.81 \pm 0.25^{* * *}$ & $1.41 \pm 0.15$ & $1.79 \pm 0.17^{*}$ & $1.73 \pm 0.1^{*}$ \\
LV diastolic D & $7.41 \pm 0.5^{* *}$ & $9.49 \pm 0.54$ & $7.31 \pm 0.11^{* * *}$ & $7.54 \pm 0.13^{* * *}$ \\
LV systolic D & $4.01 \pm 0.3^{* * *}$ & $6.84 \pm 0.54$ & $4.29 \pm 0.04^{* * *}$ & $4.83 \pm 0.15^{* * *}$ \\
LVEDV & $0.94 \pm 0.13^{*}$ & $1.79 \pm 0.27$ & $0.91 \pm 0.04^{* * *}$ & $0.99 \pm 0.17^{* * *}$ \\
LVESV & $0.18 \pm 0.01^{* * *}$ & $0.74 \pm 0.16$ & $0.21 \pm 0.02^{* * *}$ & $0.26 \pm 0.07^{* * *}$ \\
EF & $78.23 \pm 2.16^{* * *}$ & $59.3 \pm 4.79$ & $76.6 \pm 1.18^{* * *}$ & $71.1 \pm 1.52$ \\
FS & $42.5 \pm 3.53^{* *}$ & $28 \pm 3.1$ & $40.7 \pm 1.27^{* * *}$ & $37.24 \pm 1.09$ \\
\hline
\end{tabular}


GCSF-treated or saline groups (Fig. 8D-F). Thus, SP clearly decreased the ischemic area and fibrosis, and increased neo-vascularization with the vessels encircled by $\alpha$-SMA-expressing pericytes, even after permanent LAD ligation.

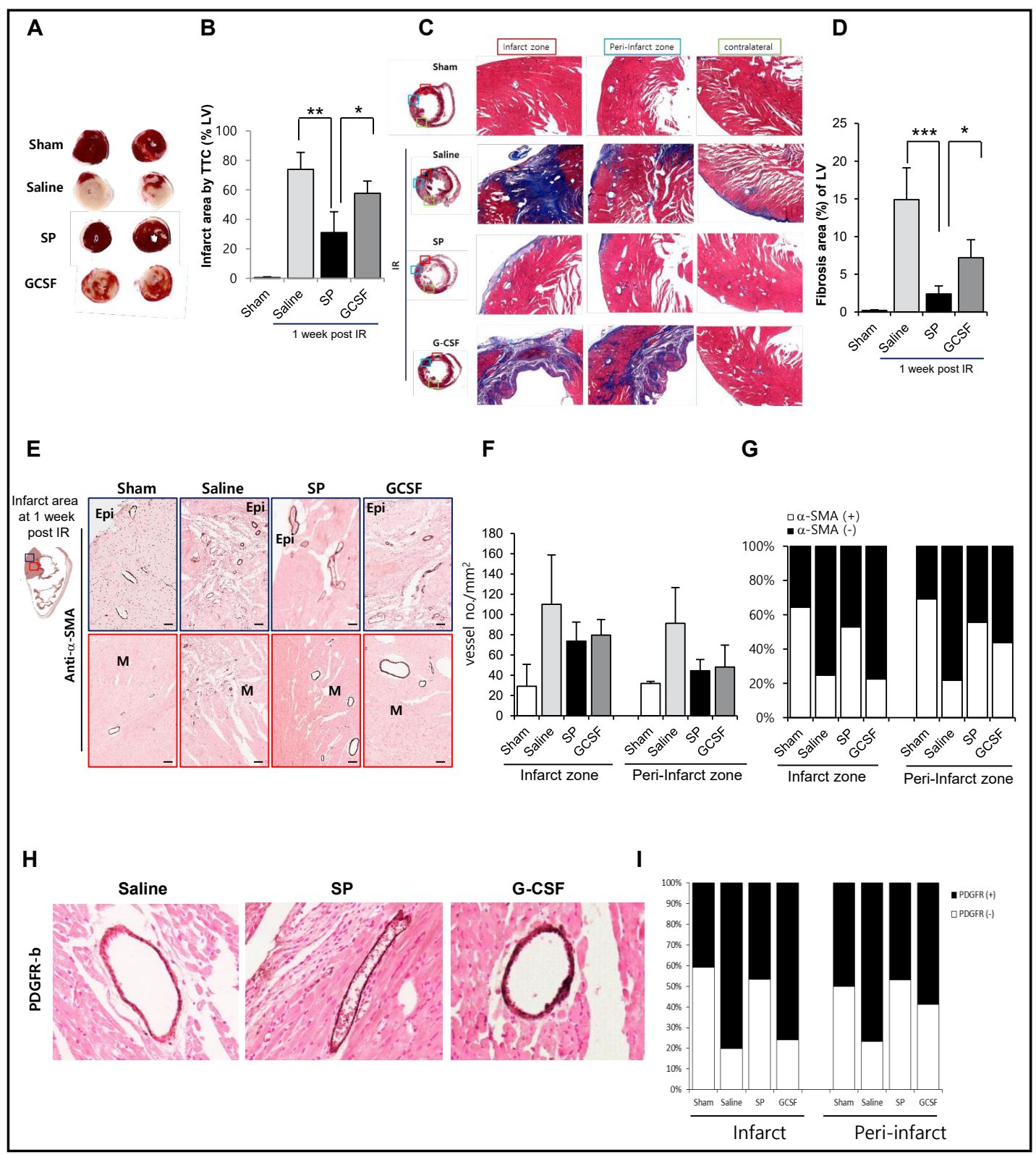

Fig. 6. Substance $P$ (SP)-mediated improvement by reducing the infarction size and fibrosis and by increasing revascularisation with $\alpha$-SMA-covered vessels, compared with these parameters after granulocyte colony-stimulating factor (GCSF) injection. (A) Representative images of the infarct zone after triphenyltetrazolium chloride (TTC) staining. (B) Quantitative analysis of the TTC-positive area. (C, D) Masson trichrome (MTC) staining was performed to measure fibrosis. (E) Immunohistochemical staining for the pericyte marker, $\alpha$-SMA, in the infarct and peri-infarct zone. Quantitative analysis of vessel numbers (F) and the ratio of $\alpha$-SMA+ cell-encircled vessels to the total number of vessels $(G)$. (H, I) Immunohistochemical staining for PDGFR-b in cardiac tissue post IR. PDGFR-b (+) vessels of total vessels was represented by the percentage. Sham-operated $(n=5)$, ischemia reperfusion injury (IRI) + saline $(n=10), I R I+\operatorname{SP}(n=10), \operatorname{IRI}+\operatorname{GCSF}(n=10)$. The data are shown as the mean \pm SD. ${ }^{*} p<0.05,{ }^{* *} p<0.01$, $* * * \mathrm{p}<0.001$. 


\section{Discussion}

During cardiac IRI, endogenous SP production was immediately induced at the injured site and subsequently in the blood. However, this injury-induced elevation in SP could only mildly stimulate EPC and BMSC mobilization, at levels that were notsufficient to facilitate tissue repair. By injecting SP immediately after IRI, SP suppressed IRI-mediated TNF- $\alpha$ induction; increased IL-10, M2-phenotype monocytes, and $\mathrm{T}_{\text {reg }} \mathrm{s}$ in the PB; and reduced myocardial apoptosis on day 1 post-IRI, all of which preceded the substantial mobilization of reparative stem cells, which occurred 3-5 days after i.v. injection. Efficacy of SP for the recovery

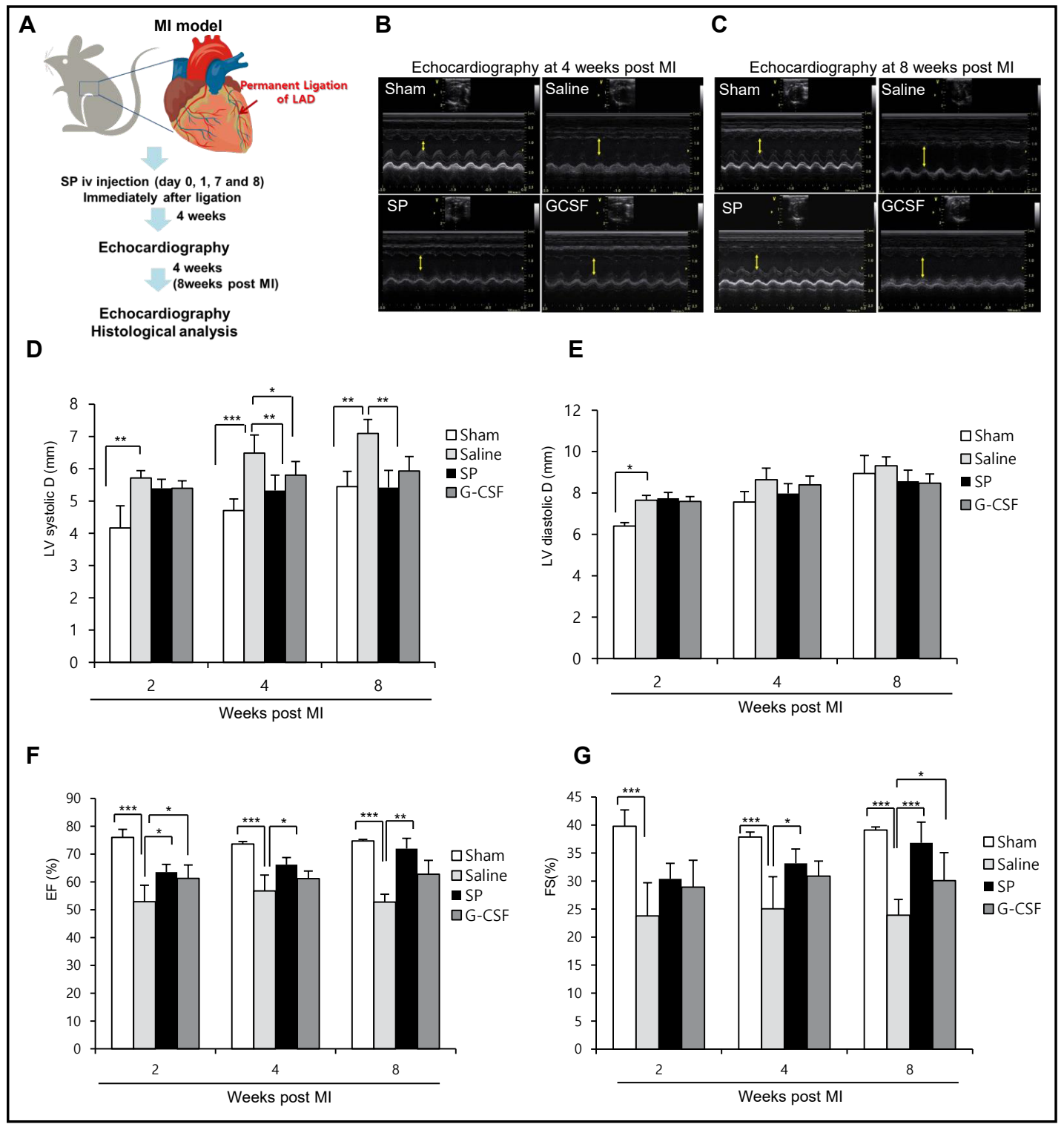

Fig. 7. Substance $P(S P)$ injection markedly improved cardiac function under permanent ligation of the left anterior descending (LAD) coronary artery. The LAD coronary artery was permanently ligated. Sham, saline, SP, or granulocyte colony- stimulating factor (GCSF) was intravenously injected twice a week for 2 weeks, and heart function was monitored at 4 and 8 weeks. (A) Scheme for myocardial-infarction model. (B, C) Representative echocardiogram images. The left ventricle (LV) systolic dimension (D), LV diastolic dimension (E), \%EF (ejection fraction) (F), and \%FS (fractional shortening) (G) were measured. $n=6$ per group. The data are shown as the mean \pm SD. ${ }^{*} \mathrm{p}<0.05,{ }^{* *} \mathrm{p}<0.01,{ }^{* * *} \mathrm{p}<0.001$. 
of cardiac function was demonstrated by increased left ventricle (LV) systolic function, reduced infarction sizes, reduced fibrosis, and increased revascularization with $\alpha$-SMA-covered vessels; these effects mediated by SP were superior to those achieved with GCSF. Furthermore, in the permanent LAD ligation model, which requires more extensive tissue repair and neovascularization for an extended period, the beneficial effect of SP on cardiac function recovery was reconfirmed by repeated treatments for 2 weeks. These findings indicated that SP orchestrates tissue repair by suppressing injurymediated inflammatory responses at an early stage, possibly leading to reduced apoptosis, and helped to prepare a better microenvironment for the survival and engraftment of the incoming SP-mobilized reparative stem cells. SP injection immediately after IRI stimulated cardiac function recovery, while reducing fibrosis and the proportion of ischemic tissue. In contrast, GCSF injection resulted in much less recovery of cardiac function.

Pericytes closely encircle endothelial cells in capillaries and microvessels, and regulate microvessel contractility and tightness; especially in the blood brain barrier and retina [29-32].The importance of pericytes in the maintenance and preservation of healthy tight microvessels has been recognized in micro-aneurysms, which feature the loss of pericytes [33]. Thus, both pericytes and endothelial cells are equally important components for healthy tight vascular regenerationinsitu. Based on our findings, the dual cell mobilization capacity of SP could be considered for use in the recovery of vascular integrity and vessel tightness in critical vascular disease including retinopathy and strokes in the future.
Table 3. Echocardiographic analysis post MI. HR, heart rate; IVS, interventricular septal thickness in diastole; PW, posterior wall thickness in diastole; LVMI, left ventricular mass index; LV diastolic D, left ventricle diastolic dimension; LV systolic D, left ventricle systolic dimension; LVEDV, LV end diastolic volume; LVESV, LV end systolic volume; EF, ejection fraction; FS, fractional shortening. Values represent mean \pm SEM. ${ }^{*} \mathrm{p}<0.05,{ }^{* *} \mathrm{p}<0.01,{ }^{* *} \mathrm{p}<0.001$ (compared with Saline)

\begin{tabular}{|c|c|c|c|c|}
\hline Parameter & Sham & Saline & SP & GCSF \\
\hline \multicolumn{5}{|c|}{2 weeks post MI } \\
\hline $\mathrm{HR}$ & $294.5 \pm 4.5$ & $271.0 \pm 8.8$ & $247.8 \pm 5.2$ & $264.8 \pm 11.2$ \\
\hline IVS & $0.97 \pm 0.05$ & $1.01 \pm 0.05$ & $1.00 \pm 0.03$ & $1.01 \pm 0.04$ \\
\hline PW & $1.02 \pm 0.05$ & $1.10 \pm 0.03$ & $1.11 \pm 0.01$ & $1.10 \pm 0.02$ \\
\hline LV diastolic D & $6.41 \pm 0.12^{*}$ & $7.65 \pm 0.10$ & $7.75 \pm 0.10$ & $7.59 \pm 0.12$ \\
\hline LV systolic D & $4.17 \pm 0.49^{* *}$ & $5.71 \pm 0.12$ & $5.40 \pm 0.14$ & $5.40 \pm 0.12$ \\
\hline LVEDV & $0.76 \pm 0.19$ & $0.94 \pm 0.05$ & $1.03 \pm 0.04$ & $0.97 \pm 0.04$ \\
\hline LVESV & $0.19 \pm 0.06$ & $0.44 \pm 0.02$ & $0.38 \pm 0.03$ & $0.38 \pm 0.02$ \\
\hline $\mathrm{EF}$ & $75.98 \pm 2.07^{* * *}$ & $52.87 \pm 2.96$ & $63.53 \pm 1.34^{* *}$ & $61.26 \pm 2.40^{*}$ \\
\hline FS & $39.78 \pm 1.68^{* * *}$ & $23.78 \pm 1.78$ & $30.40 \pm 0.92^{*}$ & $28.92 \pm 1.61$ \\
\hline \multicolumn{5}{|c|}{4 weeks post MI } \\
\hline $\mathrm{HR}$ & $249.0 \pm 4.0$ & $289.5 \pm 1.0$ & $281.8 \pm 14.1$ & $253.5 \pm 7.5$ \\
\hline IVS & $1.07 \pm 0.00$ & $1.07 \pm 0.03$ & $1.02 \pm 0.02$ & $1.02 \pm 0.06$ \\
\hline PW & $1.10 \pm 0.03$ & $1.20 \pm 0.04$ & $1.05 \pm 0.03$ & $1.06 \pm 0.13$ \\
\hline LV diastolic D & $7.57 \pm 0.36$ & $8.64 \pm 0.19$ & $7.98 \pm 0.32$ & $8.40 \pm 0.17$ \\
\hline LV systolic D & $4.701 \pm 0.26^{* * *}$ & $6.49 \pm 0.23$ & $5.33 \pm 0.19^{* *}$ & $5.80 \pm 0.17^{*}$ \\
\hline LVEDV & $0.97 \pm 0.13$ & $1.33 \pm 0.10$ & $0.97 \pm 0.04$ & $1.25 \pm 0.10$ \\
\hline LVESV & $0.26 \pm 0.04^{*}$ & $0.58 \pm 0.07$ & $0.33 \pm 0.02^{*}$ & $0.50 \pm 0.06$ \\
\hline $\mathrm{EF}$ & $73.61 \pm 0.63^{* * *}$ & $56.74 \pm 2.87$ & $66.19 \pm 1.28^{*}$ & $61.20 \pm 1.35$ \\
\hline FS & $37.86 \pm 0.44^{* * *}$ & $25.04 \pm 1.34$ & $33.16 \pm 0.88^{* * *}$ & $30.88 \pm 1.36^{* *}$ \\
\hline \multicolumn{5}{|c|}{8 weeks post MI } \\
\hline $\mathrm{HR}$ & $256.0 \pm 0.0$ & $251.3 \pm 8.3$ & $258.5 \pm 8.3$ & $267.3 \pm 7.8$ \\
\hline IVS & $1.38 \pm 0.05$ & $1.51 \pm 0.03$ & $1.38 \pm 0.13$ & $1.20 \pm 0.13^{*}$ \\
\hline PW & $1.43 \pm 0.15$ & $1.48 \pm 0.08$ & $1.50 \pm 0.07$ & $1.28 \pm 0.08$ \\
\hline LV diastolic D & $8.95 \pm 0.62$ & $9.32 \pm 0.21$ & $8.58 \pm 0.36$ & $8.47 \pm 0.13$ \\
\hline LV systolic D & $5.45 \pm 0.34^{* *}$ & $7.10 \pm 0.22$ & $5.42 \pm 0.27^{* *}$ & $5.93 \pm 0.22$ \\
\hline LVEDV & $1.54 \pm 0.29$ & $1.70 \pm 0.10$ & $1.37 \pm 0.17$ & $1.32 \pm 0.06$ \\
\hline LVESV & $0.39 \pm 0.07^{* * *}$ & $0.81 \pm 0.07$ & $0.39 \pm 0.05^{* * *}$ & $0.49 \pm 0.05^{* * *}$ \\
\hline $\mathrm{EF}$ & $74.74 \pm 0.39^{* * *}$ & $52.75 \pm 1.40$ & $71.97 \pm 1.85^{* * *}$ & $62.76 \pm 2.50^{*}$ \\
\hline FS & $39.11 \pm 0.46^{* * *}$ & $23.91 \pm 0.78$ & $36.83 \pm 1.50^{* * *}$ & $30.08 \pm 1.66^{*}$ \\
\hline
\end{tabular}




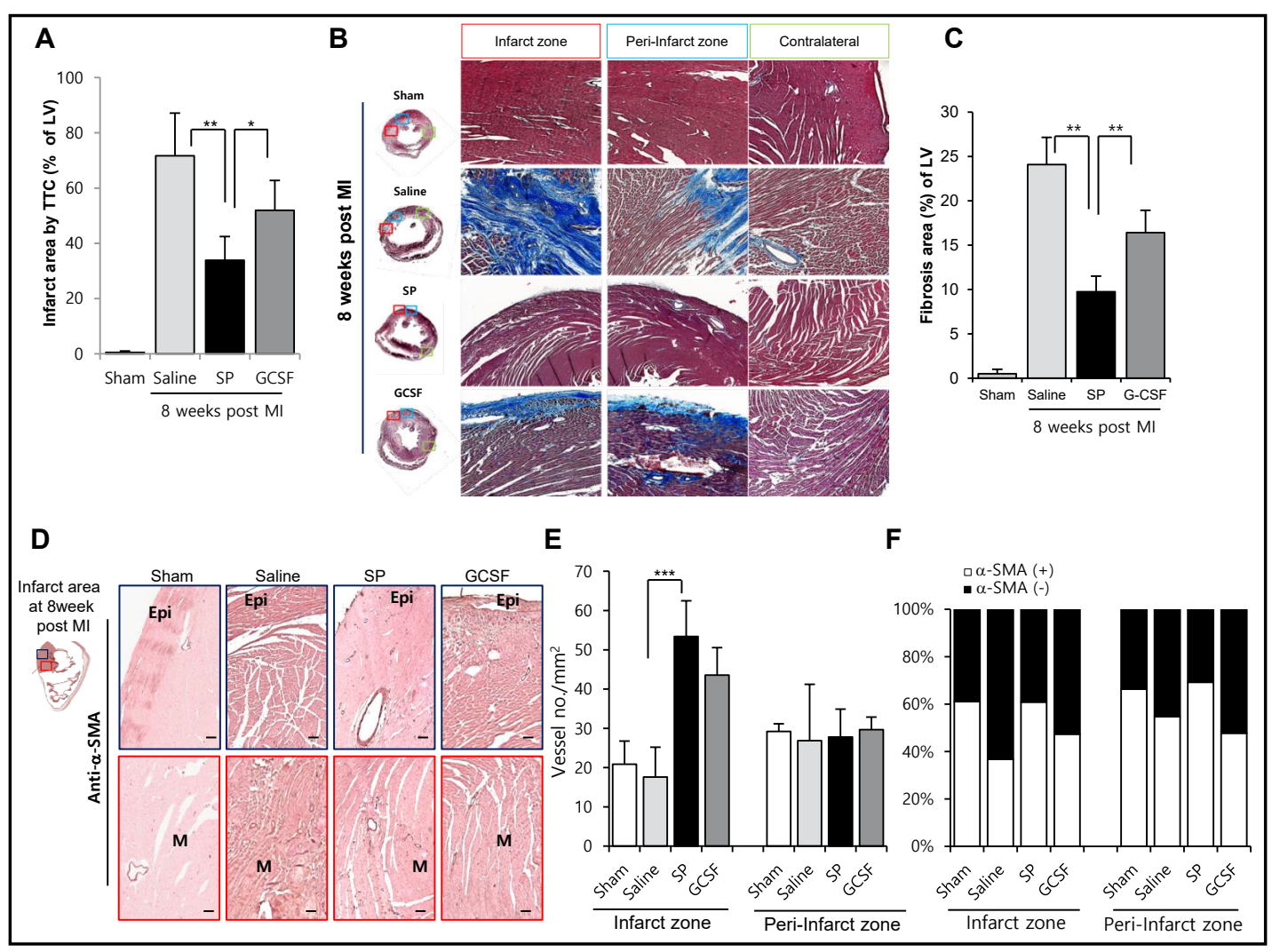

Fig. 8. Substance $P(S P)$ treatments markedly improved cardiac function by reducing the infarct size and fibrosis after permanent ligation of the left anterior descending (LAD) artery. (A) Triphenyltetrazolium chloride (TTC) staining at 8 weeks post-LAD ligation was performed to examine the infarct area. (B, C) The fibrotic area in the cardiac tissue was examined by Masson trichrome (MTC) staining and was quantitatively evaluated. (D) Representative immunostaining images for $\alpha$-SMA+ vasculature in the infarct zone. EP: epicardium, M: myocardium. Scale bar: $100 \mu \mathrm{m}$. Quantitative analysis of vessel density (E), and ratio of $\alpha$-SMA+ vessels to the total number of vessels $(F)$ in the infarct, peri-infarct, and contralateral zones at 8 weeks post-LAD ligation. $\mathrm{n}=6$ per group. The data shown reflect the mean \pm SD. ${ }^{*} \mathrm{p}<0.05$, ${ }^{* *} \mathrm{p}<0.01,{ }^{* * *} \mathrm{p}<0.001$.

Independently of its dual cell mobilizing capacity, SP exerts a systemic anti-inflammatory effect at the early stage of various acute tissue injuries. In our study, the benefits of the anti-inflammatory effect of SP on the progression of wound healing were demonstrated to be much better in comparison with GCSF, since GCSF clearly and substantially prolonged injury-triggered inflammatory responses [34], which would deleteriously affect the wound environment and delay healing. As shown in the IRI rat model, SP could exert its antiinflammatory role as early as $4.5 \mathrm{~h}$ by blunting the IRI-induced increase in TNF- $\alpha$ and increasing IL-10, CD11b+/CD206+ M2-phenotype monocytes, and CD4+/Foxp3+ $\mathrm{T}_{\text {reg }}$ cell levels in the PB. In contrast, GCSF further extended the duration of the IRI-induced increase in TNF- $\alpha$ up to day 3 post-IRI. In the present study, we did not determine by how much the anti-inflammatory effect of SP benefited tissue repair; however, it was evident that the SPinjected group showed less apoptotic cell death compared with that in the GCSF-injected group on day 1 post-IRI. Based on the kinetics of EPC and BMSC mobilization, which took 3-5 days, and the detection of biotin-SP-bound CD11b+ and CD4+ PBMCs as early as 10 min post-SP injection, the role of SP in the control of inflammation may be mediated through CD11b+/CD206+M2 macrophages and CD4+/Foxp3 $+\mathrm{T}_{\text {reg }}$ cells in the blood, rather than through the immune-modulating effect expected from SP-mobilized BMSCs in the circulation. The functional recovery mediated by SP in the IRI model and permanent LAD 


\section{Cellular Physiology Cell Physiol Biochem 2019;52:40-56 \\ \begin{tabular}{ll|l} 
and Biochemistry & $\begin{array}{l}\text { DOl: 10.33594/000000004 } \\
\text { Published online: } 18 \text { February } 2019\end{array}$ & $\begin{array}{l}\text { C 2019 The Author(s). Published by } \\
\text { Cell Physiol Biochem Press GmbH\&Co. KG }\end{array}$ \\
\cline { 2 - 3 }
\end{tabular} \\ Hong et al.: Substance-P Inhibits Cardiac Ischemia-Reperfusion Injury}

ligation model was consistently better than that achieved by GCSF injection. Thus, the earlier blockade of injury-mediated inflammatory responses caused by SP treatment might create an inflammation-suppressive and anti-apoptotic microenvironment at the injury site, resulting in the reduction of inflammation-induced secondary cell death and fibrosis, thus preparing a favorable microenvironment for the engraftment of the incoming reparative stem cells. Finally, both BMSCs and EPCs mobilized by SP are anticipated to participate in tissue repair as reparative stem cells in a concerted manner.

\section{Conclusion}

Our findings demonstrated that the systemic application of SP improved recovery of cardiac function in a rat cardiac injury model.

\section{Acknowledgements}

This study was supported by the Bio \& Medial Technology Development Program (NRF2012M3A9C6050499 and NRF2012M3A9C6050507) and Basic Science Research Program (2018R1D1A1B07049568) of the National Research Foundation, Republic of Korea and by a Korean Health Technology R\&D Project grant from the Ministry of Health \& Welfare, Republic of Korea (HI18C1492).

\section{Disclosure Statement}

The authors have no conflicts of interest to declare.

\section{References}

1 Dimmeler S, Burchfield J, Zeiher AM: Cell-based therapy of myocardial infarction. Arterioscler Thromb Vasc Biol 2008;28:208-216.

2 Beltrami AP, Barlucchi L, Torella D, Baker M, Limana F, Chimenti S, Kasahara H, Rota M, Musso E, Urbanek K, Leri A, Kajstura J, Nadal-Ginard B, Anversa P: Adult cardiac stem cells are multipotent and support myocardial regeneration. Cell 2003;114:763-776.

- 3 Chavakis E, Koyanagi M, Dimmeler S: Enhancing the outcome of cell therapy for cardiac repair: progress from bench to bedside and back. Circulation 2010;121:325-335.

- 4 Asahara T, Masuda H, Takahashi T, Kalka C, Pastore C, Silver M, Kearne M, Magner M, Isner JM: Bone marrow origin of endothelial progenitor cells responsible for postnatal vasculogenesis in physiological and pathological neovascularization. Circ Res 1999;85:221-228.

- 5 Hill JM, Zalos G, Halcox JP, Schenke WH, Waclawiw MA, Quyyumi AA, Finkel T: Circulating endothelial progenitor cells, vascular function, and cardiovascular risk. N Engl J Med 2003;348:593-600.

- 6 Takahashi T, Kalka C, Masuda H, Chen D, Silver M, Kearney M, Magner M, Isner JM, Asahara T: Ischemia- and cytokine-induced mobilization of bone marrow-derived endothelial progenitor cells for neovascularization. Nat Med 1999;5:434-438.

7 Grunewald M, Avraham I, Dor Y, Bachar-Lustig E, Itin A, Jung S, Chimenti S, Landsman L, Abramovitch R, Keshet E: VEGF-induced adult neovascularization: recruitment, retention, and role of accessory cells. Cell 2006;124:175-189.

- 8 Ruiz de Almodovar C, Luttun A, Carmeliet P: An SDF-1 trap for myeloid cells stimulates angiogenesis. Cell 2006;124:18-21.

- 9 Hattori K, Heissig B, Tashiro K, Honjo T, Tateno M, Shieh JH, Hackett NR, Quitoriano MS, Crystal RG, Rafii S, Moore MA: Plasma elevation of stromal cell-derived factor-1 induces mobilization of mature and immature hematopoietic progenitor and stem cells. Blood 2001;97:3354-3360. 


\section{Cellular Physiology Cell Physiol Biochem 2019;52:40-56 \begin{tabular}{l|l}
\hline DOI: 10.33594/000000004 & (c) 2019 The Author(s). Published by
\end{tabular} and Biochemistry Published online: 18 February 2019 Cell Physiol Biochem Press GmbH\&Co. KG \\ Hong et al.: Substance-P Inhibits Cardiac Ischemia-Reperfusion Injury}

10 Broxmeyer HE, Orschell CM, Clapp DW, Hangoc G, Cooper S, Plett PA, Liles WC, Li X, Graham-Evans B, Campbell TB, Calandra G, Bridger G, Dale DC, Srour EF: Rapid mobilization of murine and human hematopoietic stem and progenitor cells with AMD3100, a CXCR4 antagonist. J Exp Med 2005;201:13071318.

- 11 Bai X, Yan Y, Song YH, Seidensticker M, Rabinovich B, Metzele R, Bankson JA, Vykoukal D, Alt E: Both cultured and freshly isolated adipose tissue-derived stem cells enhance cardiac function after acute myocardial infarction. Eur Heart J 2009;31:489-501.

- 12 Armulik A, Abramsson A, Betsholtz C: Endothelial/pericyte interactions. Circ Res 2005;97:512-523.

- 13 Armulik A, Genové G, Betsholtz C: Pericytes: developmental, physiological, and pathological perspectives, problems, and promises. Dev Cell 2011;21:193-215.

14 Bergers G, Song S: The role of pericytes in blood-vessel formation and maintenance. Neuro Oncol 2005;7:452-464.

15 Crisan M, Yap S, Casteilla L, Chen CW, Corselli M, Park TS, Andriolo G, Sun B, Zheng B, Zhang L, Norotte C, Teng PN, Traas J, Schugar R, Deasy BM, Badylak S, Buhring HJ, Giacobino JP, Lazzari L, Huard J, et al.: A perivascular origin for mesenchymal stem cells in multiple human organs. Cell Stem Cell 2008;11:301-313.

16 Mills SJ, Cowin AJ, Kaur P: Pericytes, Mesenchymal Stem Cells and the Wound Healing Process. Cells 2015;2:621-634.

- 17 Honold J, Lehmann R, Heeschen C, Walter DH, Assmus B, Sasaki K, Martin H, Haendeler J, Zeiher AM, Dimmeler S: Effects of granulocyte colony stimulating factor on functional activities of endothelial progenitor cells in patients with chronic ischemic heart disease. Arterioscler Thromb Vasc Biol 2006;26:2238-2243.

18 Renzi D, Pellegrini B, Tonelli F, Surrenti C, Calabrò A: Substance P (neurokinin-1) and neurokinin A (neurokinin-2) receptor gene and protein expression in the healthy and inflamed human intestine. Am J Pathol 2000;157:1511-1522.

19 Hong HS, Lee J, Lee E, Kwon YS, Lee E, Ahn W, Jiang MH, Kim JC, Son Y: A new role of substance P as an injury-inducible messenger for mobilization of CD29 (+) stromal-like cells. Nat Med 2009;115:425-435.

20 Jiang MH, Chung E, Chi GF, Ahn W, Lim JE, Hong HS, Kim DW, Choi H, Kim J, Son Y: Substance P induces M2type macrophages after spinal cord injury. Neuroreport 2012;23:786-792.

21 Jiang MH, Lim JE, Chi GF, Ahn W, Zhang M, Chung E, Son Y: Substance P reduces apoptotic cell death possibly by modulating the immune response at the early stage after spinal cord injury. Neuro Rep 2013;24:846-851.

22 Hong HS, Son Y: Substance P ameliorates collagen II-induced arthritis in mice via suppression of the inflammatory response. Biochem Biophys Res Commun 2014;453:179-184.

23 Hong HS, Kim S, Nam S, Um J, Kim YH, Son Y: Effect of substance P on recovery from laser-induced retinal degeneration. Wound Repair Regen 2015;2:268-277.

24 Park JH, Kim S, Hong HS, Son Y: Substance P promotes diabetic wound healing by modulating inflammation and restoring cellular activity of mesenchymal stem cells. Wound Repair Regen 2016;24:337-348.

- 25 Lian WS, Lin H, Cheng WT, Kikuchi T, Cheng CF: Granulocyte-CSF induced inflammation-associated cardiac thrombosis in iron loading mouse heart and can be attenuated by statin therapy. J Biomed Sci 2011;18:26.

26 Ohtsuka M, Takano H, Zou Y, Toko H, Akazawa H, Qin Y, Suzuki M, Hasegawa H, Nakaya H, Komuro I: Cytokine therapy prevents left ventricular remodeling and dysfunction after myocardial infarction through neovascularization. FASEB J 2014;18:851-853.

27 Galiano RD, Tepper OM, Pelo CR, Bhatt KA, Callaghan M, Bastidas N, Bunting S, Steinmetz HG, Gurtner GC: Topical vascular endothelial growth factor accelerates diabetic wound healing through increased angiogenesis and by mobilizing and recruiting bone marrow-derived cells. Am J Pathol 2004;164:19351947.

28 Lin RZ, Dreyzin A, Aamodt K, Dudley AC, Melero-Martin JM: Functional endothelial progenitor cells from cryopreserved umbilical cord blood. Cell Transplant 2011;20:515-522.

29 Andreeva ER, Pugach IM, Gordon D, Orekhov AN: Continuous subendothelial network formed by pericytelike cells in human vascular bed. Tissue Cell 1998;30:127-135.

- 30 Nehls V, Drenckhahn D: Heterogeneity of microvascular pericytes for smooth muscle type alpha-actin. J Cell Biol 1991;113:147-154.

- 31 Peppiatt CM, Howarth C, Mobbs P, Attwell D: Bidirectional control of CNS capillary diameter by pericytes. Nature 2006;443:700-704. 


\section{Cellular Physiology Cell Physiol Biochem 2019;52:40-56}

\begin{tabular}{ll|ll} 
and Biochemistry & DOl: 10.33594/000000004 & O 2019 The Author(s). Published by \\
Published online: 18 February 2019 & Cell Physiol Biochem Press GmbH\&Co. KG
\end{tabular}

Hong et al.: Substance-P Inhibits Cardiac Ischemia-Reperfusion Injury

- 32 Trost A, Lange S, Schroedl F, Bruckner D, Motloch KA, Bogner B, Kaser-Eichberger A, Strohmaier C, Runge C, Aigner L, Rivera FJ, Reitsamer HA: Brain and Retinal Pericytes: Origin, Function and Role. Front Cell Neurosci 2016;10:20.

- 33 Xu S, Höglund M, Hâkansson L, Venge P: Granulocyte colony-stimulating factor (G-CSF) induces the production of cytokines in vivo. Br J Haematol 2000;108:848-853.

- 34 Moon JY, Woo JS, Seo JW, Lee A, Kim DJ, Kim YG, Kim SY, Lee KH, Lim SJ, Cheng XW, Lee SH, Kim W: The dose-dependent organ-specific effects of a dipeptidyl peptidase-4 inhibitor on cardiovascular complications in a model of type 2 diabetes. PLoS One 2016;11:e0150745. 